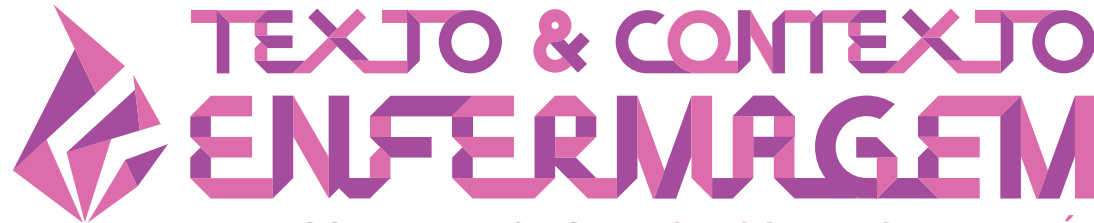

\section{POTENTIALITIES AND LIMITS OF THE CLINICAL ETHICS COMMITTEE AND NURSE PARTICIPATION: REFLECTIONS}

\author{
Luciana Neves da Silva Bampi ${ }^{1}$ (D) \\ Lydia Feito Grande ${ }^{2}$ (1)
}

${ }^{1}$ Universidade Federal de Santa Catarina, Departamento de Enfermagem. Florianópolis, Santa Catarina, Brasil. 2Universidad Complutense de Madrid, Faculdade de Medicina, Departamento de Medicina Preventiva, Saúde Pública e História da Ciência. Madrid, Spain.

\begin{abstract}
Objective: to reflect on the importance of the participation of nurses in the Clinical Ethics Committee in Brazil and the knowledge required for this performance.

Method: reflection based on experience of a postdoctoral internship carried out within the Department of Preventive Medicine, Public Health and History of Science of the School of Medicine of Universidad Complutense de Madrid, Madrid, Spain.

Results: the Clinical Ethics Committee contributes to the improvement of health care provided by professionals and health institutions. The nurses are key participants, not only because they are professionals involved in the clinical practice, committed to the decision-making and the patient's performance, but also because they vision is necessary and irreplaceable in an environment of deliberation in which different perspectives and approximations for prudent resolution of ethical conflicts.

Conclusion: if the nurses want to assume a strategic position, positively influencing the quality of care provided, protecting interests and ensuring the well-being of the users, they should assume as an urgent basis the need to develop the skills required to deal with ethical problems in the day-to-day of their care practice, accepting the responsibility to participate in the Clinical Ethics Committees, promoting their creation and inserting themselves into their activities.
\end{abstract}

DESCRIPTORS: Nursing. Nurse. Clinical ethics committee. Ethical consultation. Bioethics. 


\section{POTENCIALIDADES E LIMITES DO COMITÊ DE ÉTICA HOSPITALAR E A PARTICIPAÇÃO DO ENFERMEIRO: REFLEXÕES}

\section{RESUMO}

Objetivo: refletir sobre a importância da participação dos enfermeiros nos Comitês de Ética Hospitalar no Brasil e os conhecimentos requeridos para essa atuação.

Método: reflexão baseada em experiência de um estágio pós-doutoral realizado no âmbito do Departamento de Medicina Preventiva, Saúde Pública e História da Ciência da Faculdade de Medicina da Universidad Complutense de Madrid, Madrid, Espanha.

Resultados: o Comitê de Ética Hospitalar contribui para melhoria da assistência à saúde prestada por profissionais e instituições sanitárias. O enfermeiro é partícipe fundamental, não somente por ser um profissional implicado na prática clínica, comprometido com a tomada de decisão e a atuação do paciente, mas também porque sua visão é necessária e insubstituível em um ambiente de deliberação no qual se consideram diferentes perspectivas e aproximações para resolução prudente de conflitos éticos.

Conclusão: se os enfermeiros desejam assumir posição estratégica, influenciando positivamente a qualidade do atendimento prestado, protegendo os interesses e garantindo o bem-estar dos usuários, devem assumir como urgente a necessidade de desenvolver as competências requeridas para lidar com problemas éticos no dia a dia da sua prática assistencial, aceitando a responsabilidade de participar do Comitês de Ética Hospitalar, promovendo sua criação e inserindo-se nas suas atividades.

DESCRITORES: Enfermagem. Enfermeiro. Comitês de ética clínica. Consultoria ética. Bioética.

\section{POTENCIALIDADES Y LÍMITES DEL COMITÉ DE ÉTICA ASISTENCIAL Y PARTICIPACIÓN DEL ENFERMERO: REFLEXIONES}

\section{RESUMEN}

Objetivo: reflexionar sobre la importancia de la participación de los enfermeros en los Comités de Ética Asistencial en Brasil y los conocimientos requeridos para su actuación.

Método: reflexión basada en la experiencia de una pasantía post-doctoral realizada en el ámbito del Departamento de Medicina Preventiva, Salud Pública e Historia de la Ciencia de la Facultad de Medicina de la Universidad Complutense de Madrid, España.

Resultados: el Comité de Ética Asistencial contribuye para mejorar la asistencia a salud, prestada por los profesionales y las instituciones sanitarias. El enfermero es partícipe fundamental, no solo por ser un profesional implicado en la práctica clínica, comprometido con la toma de decisión y la actuación del paciente, sino también porque su visión es necesaria e irremplazable en un ambiente de deliberación en el cual se consideran diferentes perspectivas y aproximaciones para resolución prudente de conflictos éticos.

Conclusión: si los enfermeros pretenden asumir un rol estratégico y ejercer una influencia positiva sobre la calidad de la atención que se brinda, a fin de proteger los intereses y garantizar el bienestar de los usuarios, deben asumir como urgente la necesidad de desarrollar las competencias requeridas para lidiar con problemas éticos que surjan en su práctica asistencial cotidiana y aceptar la responsabilidad de participar en los Comités de Ética Asistencial, además de promover su creación e insertarse en sus actividades.

DESCRIPTORES: Enfermería. Enfermero. Comités de ética Clínica. Consultora ética. Bioética. 


\section{INTRODUCTION}

Varied ethical problems can arise in the daily routine of health care. These are conflicts of moral values or ethical duties that cause nurses, physicians or other members of the care team not to know how to act and need counseling for the best decision to be made. ${ }^{1}$ The Clinical Ethics Committees* (CEC) are independent and multidisciplinary collegiate that advise professionals, users/patients and their families and the management team of health services in the prevention or resolution of ethical conflicts generated in care practice. ${ }^{2-5}$ The CEC are advisory bodies, which are in charge for dialogue, debate and reflect on the multiple situations generated by scientific and technological advances in health care. $^{2-3}$

The CEC support and advise on moral and ethical issues involved in the health care. ${ }^{5}$ In order to accomplish this task, its members must represent the values of the citizens to which assistance in the institution is intended, especially as a moral community. ${ }^{6}$

The CEC arose from the need for the health team to share decisions that affected the lives and quality of life of patients and that represented risk and uncertainty, both due to the unpredictable results of certain therapies or interventions, as well as the valuation of risks and benefits. ${ }^{7}$ They were born from the desire to respect the legitimate autonomy of the patient as much as possible and due to the coercive legislation of some countries, such as the United States of America (USA). ${ }^{7-8}$ They emerged as a space for coherent discussion for difficult cases, which presented themselves in clinical practice, involving conflicts of values between the user/patient or their family and health professionals or the institution. ${ }^{5,7}$ Disagreements also occurred among members of the health care team, when they had different moral and ethical values. ${ }^{7}$

The CEC emerged in the USA ${ }^{2,7-8}$ with the strongly ingrained idea of protecting the patient's autonomy. ${ }^{7}$ This motivation was in accordance with the legal guidelines of that country, regarding informed consent and the patient's right not to accept certain treatment, even if that right represented the subject's death. ${ }^{7}$ The first committee was established in 1960, after setting up of the Seattle Artificial Kidney Center, in Seattle, in order to select patients who would undergo the new hemodialysis technique. ${ }^{2,7}$

In that decade, in 1967, surgeon Christian Barnard successfully performed the first heart transplant, raising the debate about the definition of death. ${ }^{2}$ This definition was only published in 1968, in Revista JAMA, through the ad hoc committee report of Harvard Medical School and led to the setting out hospital committees in order to decide on death conditions and the ethical and legal possibilities for the withdrawal of artificial respirators. ${ }^{2}$

Some particular episodes, Karen Ann Quinlan (1976), ${ }^{7}$ Baby Doe 1 (1982) and 2 (1983), ${ }^{2}$ boosted CEC creation in the USA. These cases were mediated by judicial resources and mobilized public opinion due to the mismatch between technological advances in health, the conduct of care teams and the right to choose patients and family members. ${ }^{7}$

In Europe, the protection of the individual and the community, through the CEC activities, began in Spain, in 1976, with the works of Dr. Francesc Abel i Fabre. ${ }^{9}$ This doctor answered the call of the head of the Maternity Hospital of Maternal and Child Hospital Sant Joan de Déu, in Barcelona, and joined the Family and Therapeutic Guidance Committee in order to provide a collegiate response to ethical problems in obstetrics and pediatrics. Under his guidance, the first Bioethics Committee was created at the institution, the name given to the first Spanish CEC, whose function was to analyze clinical facts in the light of ethical values and harmonize scientific rigor and ethical deliberation in

\footnotetext{
* In the national literature, Portuguese of Brazil, the Clinical Ethics Committees are also called Clinical Bioethics Committees or Bioethics Committees. In English the authors refer to the Healthcare Ethics Committees, Clinical Ethics Committee or Hospital Ethics Committee,. In Spanish the terminology to be used is Care Ethics Committees, Ethics Comitee for Health Care or Clinical Ethics Committees.
} 
situations of uncertainty or uncertainty or conflict of moral values. ${ }^{9}$ In the European reality, the CEC distanced themselves from issues related to the distribution of resources, which had been the main themes of the first committees in the USA, to dedicate themselves to the conflicts that arose in the assistance environment. $^{9}$

In Latin America, Argentina was one of the pioneering countries in the creation of ethics committees. In 1996, a national law was enacted and promulgated which determined that every hospital in the public health system should have a CEC with advisory functions. ${ }^{10}$

The Universal Declaration of Bioethics and Human Rights, of the United Nations Educational, Scientific and Cultural Organization (UNESCO), of October 19, 2005, in Article 19, listed the typology of ethics committees, among them the CEC, necessary for the application of the principles that the declaration contemplated. He also pointed out that all countries should encourage the creation of independent, interdisciplinary and pluralistic ethics committees. ${ }^{11}$

Brazil, despite being among the 191 countries that unanimously approved the draft of UNESCO Declaration, does not have a normative framework for CEC creation, operation and accreditation. Hospital das Clínicas of Porto Alegre was the pioneer in developing this activity in $1993 . .^{12}$ There is, however, no official record for the number of CEC existing in the country today. Some initiatives are known: São Paulo, Hospital das Clínicas (1996), ${ }^{13}$ and Hospital Geral de São Mateus (2008), ${ }^{14}$ Porto Alegre, Hospital São Lucas (1997) $)^{13}$ and Rio de Janeiro, Instituto Nacional do Câncer (1999) ${ }^{13}$ and Hospital Universitário Clemente Fraga Filho (2003). ${ }^{13}$ The lack of national governance for creating, operating and accrediting CEC is also a fact in other countries, such as Italy ${ }^{8}$ and Poland. ${ }^{15}$

The composition of a CEC must be interdisciplinary, including representatives of all those involved in the clinical relations. The participation of the various health-related professions must be balanced and there needs to be a qualified presence of members of society in general. ${ }^{3,5,14}$ It must have people with knowledge in ethics, bioethics and law. It is important to have a lawyer, with experience in health legislation, and community members, who represent the perspective of the users/patients, who have experience in defending human rights. $3,5,14$

The CEC have three basic functions: consultative, educational and normative. ${ }^{3-5,7-8}$ Analyzing clinical cases and providing consultancy and advice in resolving conflicts that occur between the users/patients and their families and health professionals in healthcare practice is the most required function ${ }^{3,5}$ The educational activities aim to serve the institution's professionals, especially the committee members, and the community in general. ${ }^{3,16}$ It is also necessary to assist in the development of guidelines, guides and protocols on complex ethical issues that are frequent in the institution. ${ }^{3}$

It should be noted that these are not CEC functions: direct legal support to health persons or organizations, the issuing of a judgment or control over professional conduct (for this there are the ethics and deontology commissions and the professional bodies of each profession), decision making on behalf of the users/patients, family members, health professionals, institutions or judicial authorities and carrying out expertise works. ${ }^{4}$

The CEC are advisory and deliberative bodies. Depending on the legislation of each country, they can make binding decisions or not. In Spain, decisions are not binding, do not generate norms of obligatory compliance, they are only recommendations, which aim to contribute to improving the quality of the assistance provided. ${ }^{9}$ Therefore, it is not a matter of imposing one's own ideas on others, convincing them or changing their beliefs or values. ${ }^{9}$ The function is different, namely to deliberate, to consider the factors that intervene in a concrete situation, in order to seek the optimal solution or, when this is not possible, the least harmful. ${ }^{17}$ Thus, the opinions or reports issued by the CEC do not replace or diminish the responsibility of those who have asked for advice, they only help to decide better, based on clear ethical grounds. ${ }^{18}$ 
In several countries in the world ${ }^{1,8,10,15-16}$ and in Brazil ${ }^{13-14}$ the nurses participate in the CEC. However, little is known about this participation ${ }^{1,19}$ and the skills required of this professional to be an ethical consultant and compose the CEC. ${ }^{19-20}$ In this perspective, this article aims to reflect on the importance of nurses' participation in the CEC in Brazil and the knowledge that is required from this professional for this performance. The reflections resulted from an experience lived during a postdoctoral internship carried out in the scope of the Department of Preventive Medicine, Public Health and History of Science of the School of Universidade Complutense de Madrid (UCM), Madrid, Spain. This training aimed to get to know the Spanish reality, especially the Health Service Madrileño, on CEC, creation, operation and accreditation, to establish a committee in a University Hospital in the Midwest Region of Brazil. The experiences took place through the author's effective participation in the CEC meetings of Hospital Universitário San Carlos, health institution linked to the UCM, during the six-month period, and technical visits to other CEC, including: Hospital Universitário La Paz, Hospital Ramon y Cajal, Hospital de Alcorcón and to the Social-sanitary committee of Caser Residencial La Moraleja - Fundación CASER. Nurses' participation in these CEC was particularly observed during the experience. The lived experience was recorded in a diary. By combining the observation data of the diary with the literature on CEC, ethical consultancy, participation of nurses in the CEC and ethical consultancy by nurses, the content that enabled the construction of this reflection was obtained.

\section{REFLECTIONS}

\section{CEC and the nurse's participation}

In clinical practice, in the context of care relationships, there is a need to make difficult decisions derived from the prognosis, therapeutic goals, use of technology, patient's wishes and available resources. ${ }^{18}$ Excellence in health care is just achieved by aligning technical accuracy and ethical responsibility in decision making. ${ }^{9}$ Ethical judgments, like the clinical ones, cannot disregard the real facts and the concrete situations of each case. ${ }^{18}$ Intuition or common sense are not enough to resolve the ethical problems of the clinic, as uncertainty is characteristic of these situations and their solutions are probable and verifiable ${ }^{17}$ Thus, it is best to appreciate each case, using systematic procedures for decision making. ${ }^{17}$ There are several procedures for decision making in conflict situations. ${ }^{17}$ The fundamental issue is to find and use methods that enable the rational, systematic and objective study of the problem, so that the decision made is prudent ${ }^{17}$

The cases that usually arrive at the CEC refer, among others, to: respect for autonomy and informed consent (especially in the case of invasive and life-threatening procedures); resuscitation of people in critical situation; treatment of patients without therapeutic possibilities or under terminal conditions; assessing and diagnosing brain death (especially delicate cases of children and potential organ donors); problems in high-risk pregnancy; relationships among health professionals; and limited resource management. ${ }^{5,14}$ In this context, the potential of CEC refers to the possibility of contributing to improving the quality of care provided by health professionals and institutions, ${ }^{2-3,9,14}$ corroborating, in the case of Brazil, for the National Policy for the Humanization of Health Care, of the Ministry of Health, and for the perspective of reducing health-related lawsuits, ${ }^{9,13,18}$ a reality increasingly found in the country.

To the extent that it instrumentalizes and supports prudent decision-making, of the users/ patients and their families, professionals and health institutions, to resolve ethical conflicts related to clinical care and works as a reconciling instance, endeavoring to resolve the imbroglios and reach agreement between the parties, or when this is not possible presenting the least harmful solution to 
all, the CEC contributes to the respect for the dignity of people and their inalienable rights and for the humanization of clinical relations, encouraging the autonomy of the involved people..$^{9,13-14,18}$

In relation to other functions, education and standardization, the creation of CEC in health services, helps to spread the interest in acquiring knowledge on ethical issues related to health and allows the study and deepening of these contents by the members of the committee, by professionals of the institution and by other stakeholders ${ }^{3,14,16}$ and assists in preparing, implementing and evaluating institutional guidelines on ethics in health care. ${ }^{14}$ Some examples are institutional guidelines on rights and obligations in relation to information and clinical documentation, protocols on care at the end of life and making, implementation and evaluation of informed consent terms for invasive or life-threatening procedures.

The lack of a normative and national governance framework is one of the limitations to the creation of the CEC in Brazil. Contrary to what happened with Resolution 196, revised by Resolution 466, of the National Health Council, of the Ministry of Health, which approved the guidelines and regulatory standards for research involving human beings in the country, instituted the ethical review system and obliged all research centers with a Research Ethics Committee (Comitê de Ética em Pesquisa,CEP) and the entire research protocol to be evaluated and approved by the CEP before its realization, there are no guidelines in Brazil that regulate the creation, operation and CEC accreditation. There is also no central regulating and accrediting body, such as the National Research Ethics Commission (Comissão Nacional de Ética em Pesquisa,CONEP). Consequently, the CEC are not mandatory in institutions that provide health care in the country.

The existence of a legal framework, however, does not in itself guarantee the implementation, operation and effectiveness of the CEC's works. It is necessary for health professionals and institutions to recognize it as an instance of support for decision making in ethical issues related to health. In Argentina, as well as in the USA, the emergence of the committees was linked to legal pressure and this generated problems related to acceptability by professionals and confusion regarding the functions of the CEC and CEP in the text of the law. ${ }^{10}$ In Canada, despite having evolved in the last two decades and being increasingly present in hospitals, with a primary function of counseling and education, the CEC still need to define their other areas of activity. ${ }^{21}$ In Italy, despite the existence of legislation for the creation of CEC, there is no standardization of procedures. ${ }^{8}$ In addition, most committees mix the functions related to the evaluation of research projects and counseling in the face of problems in care practice, ${ }^{8}$ that is, CEP functions are confused with those of the CEC. In Spain, before the appearance of the legal framework, health professionals and the community in general were sensitized on the CEC functions, which facilitated the process of acceptance and recognition of the committees. ${ }^{7}$

The ignorance of some health professionals and institutions in Brazil about what a CEC is and its functions, as well as the mistaken idea that this is another body for supervising professional practice or service management, ${ }^{13}$ are other limitations, which also appear in other countries. ${ }^{8,21}$ Alternatives are suggested to overcome them: Invest in bioethical training, ${ }^{9,16}$ in particular to know about international documents that guide the formation and procedures of the CEC, ${ }^{16}$ communicate all service personnel about the creation of the CEC, inviting everyone interested in participating (make it clear that this is an unpaid activity), ${ }^{14}$ inform the community on the CEC functions and the mechanisms for submitting cases for consultation ${ }^{14,16}$ and maintain communication with the professionals to determine the issues that represent ethical problems in the institution and that require the elaboration of guides or protocols of conduct. ${ }^{14,16}$

CEC creation and functioning in health institutions represents a cultural change, by admitting that health-related decisions embody values, ${ }^{22}$ that is, they are more than a purely technical practice. The CEC, with its plural composition, presents the problem from different perspectives, including that 
of the user/patient, and allows its analysis through different nuances, assisting in the formation and development of sensitivity to ethical issues, which are analyzed and resolved through moral deliberation tools. Resistances against the CEC disappear when they are perceived as useful, maintain respect for the activities and decisions of professionals and users, and serve as support and advice in solving difficult situations.

The American Society for Bioethics and Humanities defines ethical consultation as the service offered by a person or a group to help the users/patients, relatives members, health professionals and others to deal with ethical conflicts that arise in health care. ${ }^{23}$ There are three ethical consultancy classes: CEC or extended model, mixed model and individual model (ethical consultant). ${ }^{723-24}$ The extended model is the most prevalent. ${ }^{5,7-9,24}$

The professional profile of the ethical consultant or those who wish to be members of a CEC distinguishes three competence areas: Knowledge, skills and attitudes. ${ }^{23-24}$ The knowledge involves pathology, clinic, ethics, health legislation, among others. This knowledge must be continuously reviewed according to scientific and legislative progress. Three classes may be distinguished in the skills: Ethical skills, to be able to identify the ethical conflict that justifies the consultation and to be able to assess which or which information is most relevant to the case; procedural skills, to face ethical conflicts within the clinical-care context; and interpersonal skills, in order to best deal with the personal relationships raised in each case.$^{23}$ Ethical skills can be acquired through training courses in bioethics, while procedural and interpersonal skills can just be acquired through experience. ${ }^{25}$

The indicated attitudes form five groups: 1) tolerance, patience and compassion, to help people who are in difficult situations; 2) honesty and self-knowledge, to establish a climate of trust in the meetings; 3) courage, to face situations in which power struggles may occur; 4) prudence and humility, to deal with conflicts between the particular morals of each of those involved and the role of ethical consultant; 5) integrity to show healthcare professionals, users/patients and family members that the consultant is reliable to assist in resolving an ethical conflict. ${ }^{23}$

Specifically for the nurse, knowledge about ethics, legislation/regulations on health, clinic and care is considered necessary, the essence of the profession. The skills concern the use of nursing methods and techniques, communication, the faculty of defending the patient and the possibility of having a global view of the situation. These skills are commonly essential to care. The moral required skills are: Ability to recognize, analyze, synthesize, express and contest moral aspects and points of view. Respect and openness to the opinions and values of the other (committee members, users/ patients and professionals) are required nurse attitudes. The professional must also be discerning, have the capacity for reflection, interest in ethical issues and commitment to the works of the CEC, in addition to being aware of their limitations and convictions. ${ }^{20}$

The nurses are key participants in the CEC not only because they are professionals involved in the care task and, therefore, committed to the health decision-making process and the patient's autonomy, but also because their vision is necessary and irreplaceable in an environment, such as the CEC, in which different perspectives and approaches are considered in the process of moral deliberation. ${ }^{26}$

It seems unrealistic to think that all CEC members have all the characteristics required in the profile of the ethical consultant. For this reason, one of the strengths for adopting the extended ethical consultancy model, the CEC, is the possibility of complementing experiences among members, that is, each with its expertise contributes to the strengthening of the group's ethical model, ${ }^{25}$ which will ultimately enable deliberations more representative of that moral society.

Ethical consultation is currently as vital to health services as clinical consultation, because it contributes to improving the professional health/patient relationship and the care provided. ${ }^{25}$ Nurses need to be able to work to resolve moral conflicts. ${ }^{27-28}$ Integrating the CEC makes it possible to 
develop the skills necessary to resolve these disputes and is a way for reducing the professional's moral stress. ${ }^{29-30}$ The Brazilian nursing professional bodies, however, have so far not submitted any position regarding nurses' participation in the CEC. In 1994, the Federal Nursing Council (Conselho Federal de Enfermagem, COFEN), through Resolution $172^{* *}$, regulated the creation of Nursing Ethics Commissions in health institutions. These commissions are representative bodies of the Regional Nursing Councils, formed by professionals belonging to the category, with educational, advisory and guidance functions for the ethical and professional exercise of nursing professionals. ${ }^{31}$

The absence of a position regarding the participation in CEC by professional associations occurs with other professions involved in health care in the country, with the exception of the Federal Council of Medicine, which, in 2015, positioned itself recommending the creation and functioning of CEC in health institutions and the participation of doctors in the organ. ${ }^{5}$

\section{CONCLUSION}

CEC creation allows for deepening the look and for seeking solutions to moral problems that occur in hospitals and health institutions and assist in the dissemination of knowledge on ethical issues in the clinical practice. The CEC are institutionalized instruments in the service of professional improvement, quality of health care and humanization of the clinical relationship. Thus, if the nurses wish to take a strategic position to positively influence the quality of care provided, protecting and defending interests and guaranteeing the well-being of the users/patients and the relatives, they must go from clinical care to ethical reflection. For this, they must urgently assume the need for developing the skills required to deal with ethical problems in their day-to-day care practice, accepting the responsibility of participating in the CEC, promoting its creation and being inserted in its activities.

\section{REFERENCES}

1. Gaudine A, Lefort SM, Lamb M, Thorne L. Ethical conflicts with hospitals: the perspective of nurses and physicians. Nurs Ethics. [Internet] 2011 [cited 2017 Nov 13];18(6):756-66. Available from: https://dx.doi.org/10.1177\%2F0969733011401121

2. Sorokin P, Actis AM, Outomuro D. Comités de ética asistencial: de los grandes dilemas a los nuevos desafíos. Rev Bioét. [Internet] 2016 [cited 2017 Nov 18];24(1):91-7. Available from: https://dx.doi.org/10.1590/1983-80422016241110

3. Organización de las Naciones Unidas para la Educación, la Ciencia y la Cultura. División de Ética de la Ciencia y la Tecnología. Guía n 1 - Creación de Comités de Bioética. UNESCO [Internet]. 2005 [cited $2018 \mathrm{Mar}$ 08]. Available from: http://unesdoc.unesco.org/images/0013/001393/139309s.pdf

4. Conselho Federal de Medicina. Recommendation No.8, dated Thursday, March 12, 2015. Recomenda a criação, o funcionamento e a participação dos médicos nos comitês de bioética. Brasília: Conselho Federal de Medicina [Internet]. 2015 [cited 2018 Mar 08]. Available from: http://portal.cfm.org.br/images/Recomendacoes/8_2015.pdf

5. Catlin A. The hospital ethics committee and the nurse. Adv Neonatal Care. [Internet] 2014 [cited 2018 Nov 02];14(6):398-402. Available from: https://insights.ovid.com/article/00149525-201412000-00008

6. Engelhardt Jr HT. A ética da ética clínica: reflexões críticas em face da diversidade moral. Rev BioEthikos. [Internet] 2012 [cited 2017 Dec 14];6(1):11-21. Available from: https://www.saocamilosp.br/pdf/bioethikos/91/a01.pdf

\footnotetext{
${ }^{* *}$ Resolution 172 of the Federal Nursing Council was repealed and replaced by Resolution 572, of March 23, 2018.
} 
7. Pose C. Los inicios de la consultoría ética: los comités de ética y su constitución. Eidon. [Internet] 2016 [cited 2017 Nov 13];45:29-63. Available from: https://revistaeidon.es/public/journals/ pdfs/2016/45_junio.pdf

8. Leuter C, Petrucci C, Caponnetto V, La Cerra C, Lancia L. Need for ethics support in clinical practice and suggestion for an ethics consultation service: views of nurses and physicians working in italian healthcare institutions. Ann Ist Super Sanita [Internet] 2018 [cited 2018 Nov 02];:54(2):117-25. Available from: https://dx.doi.org/10.4415/ann_18_02_07

9. Abel F. Comités de Ética Asistencial. An Sist Sanit Navar. [Internet] 2006 [cited 2017 Dec 14];29(3):75-83. Available from: http://scielo.isciii.es/scielo.php?script=sci_ arttext\&pid=s1137-66272006000600008

10. Luna F, Bertomeu MJ. Comités de Ética en la Argentina. Rev Bioét [Internet]. 1998 [cited 2017 Dec 14];6(2)183-7. Available from: http://saludcolectiva-unr.com.ar/docs/sc-090.pdf

11. United Nations Educational, Scientific and Cultural Organization. Universal Declaration on Bioethics and Human Rights. UNESCO [Internet]. 2005 [cited 2018 Mar 08]. Available from: http://unesdoc.unesco.org/images/0014/001461/146180e.pdf

12. Goldim JR, Raymundo MM, Fernandes MS, Lopes MHI, Kipper DJ, Francisconi CF. Clinical Bioethics Committees: a Brazilian experience. J Int Bioethique. [Internet]. 2008 [cited 2017 Dec 14];19(1-2):181-92. Available from: https://dx.doi.org/10.3917/jib.191.0181

13. Marinho S, Costa A, Palácios M, Rego S. Implementation of bioethics committees in brazilian university hospitals: difficulties and viability. Rev Bioét. [Internet] 2014 [cited 2017 Dec 14]; 22(1):105-15. Available from: https://doi.org/10.1590/S1983-80422014000100012

14. Oliveira MCG, Oliveira RA, Nogueira-Martins MCF. The experience of the bioethics committee from a public hospital. Rev Bioét. [Internet] 2017 [cited 2018 Mar 08];25(2):338-47. Available from: https://dx.doi.org/10.1590/1983-80422017252194

15. Czarkowski M, Kaczmarczyk K, Szymańska B. Hospital ethics committees in Poland. Sci Eng Ethics. [Internet] 2015 [cited 2017 Dec 14]; 21(6):1525-35. Available from: https://link.springer. com/article/10.1007/s11948-014-9609-x

16. Alvarez JA, Moreno SL. Los comités hospitalarios de bioética y la educación en salud: notas para la discusión. Rev Latinoam Bioet. [Internet] 2016 [cited 2018 Nov 02];17(1):184-99. Available from: https://dx.doi.org/10.18359/rlbi.2343

17. Gracia D. La deliberación moral: el método de la ética clínica. Med Clin. [Internet] 2001 [cited 2017 Dec 14]; 117:18-23. Available from: https://dx.doi.org/10.1016/S0025-7753(01)71998-7

18. Couceiro A, Beca JP. Los comités de ética asistencial y las repercussiones jurídicas de sus informes. Rev Med Chile. [Internet] 2006 [cited 2017 Dec 14]; 134:517-9. Available from: https:// dx.doi.org/10.4067/S0034-98872006000400016

19. Brito GMG, Santa Rosa DO. Nurses performance in clinical ethics committees and commissions: an integrative review. Nurs Ethics. [Internet] 2017 [cited 2018 Nov 02]; 21(4):1-12. Available from: https://dx.doi.org/10.1177/0969733017724611

20. Cusveller B, Schep-Akkerman A. Towards a competency assessment tool for nurses in ethics meetings. Nurs Ethics. [Internet] 2015 [cited 2018 Nov 02];23(4):413-20. Available from: https:// dx.doi.org/10.1177\%2f0969733014567170

21. Gaudine A, Thorne L, LeFort SM, Lamb M. Evolution of hospital clinical ethics committees in Canada. J Med Ethics. [Internet] 2010 [cited 2018 Mar 08];36(3):132-7. Available from: https:// dx.doi.org/10.1136/jme.2009.032607

22. Álvarez S. Valores clave en la práctica médica. Eidon. [Internet] 2016 [cited 2017 Nov 13];(46):8393. Available from: https://revistaeidon.es/public/journals/pdfs/2016/46_diciembre.pdf 
23. Tarzian AJ, ASBH Core Competencies Update Task Force 1. Health care ethics consultation: an update on core competencies and emerging standards from the American Society for Bioethics and Humanities' core competencies update task force. Am J Bioeth. [Internet] 2013 [cited 2018 Nov 02];13(2):3-13. Available from: https://dx.doi.org/10.1080/15265161.2012.750388

24. Tarzian AJ, Wocial LD, The ASBH Clinical Ethics Consultation Affairs Committee. A code of ethics for health care ethics consultants: journey to the present and implications for the field. Am J Bioeth. [Internet] 2015 [cited 2018 Nov 02];15(5):38-51. Available from: https://dx.doi.org /10.1080/15265161.2015.1021966

25. Pose $\mathrm{C}$. El papel de las instituciones y comisiones de bioética en el desarollo de la ética asistencial. Eidon. [Internet] 2017 [cited 2018 Nov 02];(47):89-125. Available from: https://revistaeidon.es/ public/journals/pdfs/2017/47_junio.pdf

26. Grande LF. Los cuidados en la ética del siglo XXI. Enfermería Clínica. [Internet] 2005 [cited 2017 Dec 14];15(3):167-74. Available from: https://dx.doi.org/10.1016/s1130-8621(05)71104-9

27. Nora CRD, Deodato S, Vieira MMS, Zoboli ELCP. Elements and strategies for ethical decision making in nursing. Texto Contexto Enferm. [Internet] 2016 [cited 2018 Mar 08]; 25(2):e4500014. Available from: https://dx.doi.org/10.1590/0104-07072016004500014

28. Avila LI, Silveira RS, FigueiredoPP, Mancia JR, Gonçalves NGC, Barlem JGT. Moral construction of undergraduate nursing students to promote care humanization. Texto Contexto Enferm. [Internet] 2018 [cited 2018 Aug 14]; 27(3):e4790015. Available from: https://dx.doi.org/10.1590/0104070720180004790015

29. Morley G. Efficacy of the nurse ethics in reducing moral distress: what can the NHS learn from the USA? Br J Nurs. [Internet] 2016 [cited 2018 Nov 02]; 25(1):36-9. Available from: https://doi. org/10.12968/bjon.2016.25.1.36

30. Morley G. Efficacy of the nurse ethics in reducing moral distress: what can the NHS learn from the USA? Part 2. Br J Nurs [Internet]. 2016 [cited 2018 Nov 02];25(3):156-61. Available from: https://dx.doi.org/10.12968/bjon.2016.25.3.156

31. Conselho Federal de Enfermagem. Resolução 572, de 23 de março de 2018. Normatiza, no âmbito dos Conselhos Regionais de Enfermagem, a criação e funcionamento das Comissões de Ética de Enfermagem nas instituições de saúde com serviços de enfermagem. Brasília: Conselho Federal de Enfermagem. [Internet]. 2018. [cited 2018 Nov 02]. Available from: http:// www.cofen.gov.br/wp-content/uploads/2018/04/resolu\%c3\%87\%c3\%83o-cofen-572-2018.pdf 


\section{NOTES}

\section{CONTRIBUTION OF AUTHORITY}

Study desing: Bampi LNS, Grande LF.

Data collection: Bampi LNS.

Analysis and interpretation of data: Bampi LNS, Grande LF.

Discussion of the results: Bampi LNS, Grande LF.

Writing and/or critical review of content: Bampi LNS, Grande LF.

Review and final approval of the final version: Bampi LNS, Grande LF.

\section{ACKNOWLEDGMENT}

We are grateful to Clinical Ethics Committees of Hospital Universitário San Carlos, Hospital Universitário La Paz, Hospital Ramon y Cajal, Hospital de Alcorcón and the Socio-sanitary Committee of Caser Residencial La Moraleja - Fundación CASER and the Department of Preventive Medicine, Health Public and Science History of the School of Medicine of Universidad Complutense de Madrid, for the opportunity to learn and exchange experiences.

\section{CONFLICT OF INTEREST}

There is no conflict of interest.

\section{HISTORICAL}

Received: August 29, 2018.

Approved: December 3, 2018.

\section{CORRESPONDING AUTHOR}

Luciana Neves da Silva Bampi

Ibampi@unb.br 